\title{
Antarctica and Glacial Ages
}

\author{
By Prof. E. W. MacBride, F.R.S.
}

$\mathrm{T}$ HE effects and causes of glacial ages have been discussed from many points of viewobservational and theoretical-and the meteorological aspects of the problem were very clearly presented by Sir George Simpson in his Royal Institution discourse published as a Supplement to Nature of April 2. What is said in the present article may be regarded as complementary to Sir George's survey of the subject, the point of view being that of a zoologist and palæontologist instead of meteorologist or astronomer. In the collection of the facts embodied in the article, I have had the advantage of help generously afforded me by Dr. Stephenson, geologist attached to the Graham Land Expedition, and by Prof. W. W. Watts.

If we desire to know what a glacial age was really like, the obvious course is to study a part of the world where such an age is still in existence. Greenland and Antarctica are two such regions, but Antarctica is preferable to Greenland because it is of continental size. Antarctica is roughly circular in outline and has a diameter of 3,000 miles. Its area thus works out at about $7,000,000$ square miles. The maximum height of the continent is 3,168 metres or about 10,000 feet. This is situated about 200 miles north of the south pole.

The whole continent is covered with a huge ice-sheet through which only the highest peaks protrude as two volcanic cones, Mounts Erebus and Terror. The part so far principally studied is that directly south of South America, in which lies the inlet known as the Ross Sea. The length of the ice-sheet known as the Beardmore Glacier flowing into the Ross Sea is about two hundred miles, but it joins the great barrier ice-shelf which extends several hundred miles farther out to sea and from the outer edge of which great tabular icebergs are constantly being cut off. If we add the breadth of the ice-shelf to the length of the Beardmore Glacier, we arrive at a total extent of ice-flow of about five hundred miles, and this is considerably longer than any glacier the existence of which we have evidence in the Pleistocene Glacial Age. From the evidence of erratics carried on the glacier, Dr. Stephenson has been able to make a rough guess as to the nature of the geological formations buried beneath it. Rocks of the Gondwana age, with coal-seams carrying characteristic fern plants, are present: the Gondwana age is usually described as Permo-Carboniferous. Beneath it are folded schists of the Pre-Cambrian or Huronian age.

Now, rocks of Gondwana age with the same characteristic fossil plants are found also in the Deccan of India, in South Africa, and South America; and it is evident that all four areas formed parts of a southern continent for which the name of Gondwanaland has been adopted. It is clear that this continent during the early part of the Gondwana age enjoyed a mild climate and hence must have been situated a considerable distance from the pole; but later it underwent $a_{0}$ severe glaciation known as the Gondwana ice-age. Antarctica, however, which formed part of this continent, entirely escaped this glaciation. We conclude, therefore, that during this period the continent must have drifted across the south pole but that Antarctica, which formed part of its northern edge, escaped this glaciation. The drift then must have originated to the south of Australia, and as Australia itself formed part of Gondwana. land, the drift must have begun after the breaking off of Australia from the rest.

The point which we wish to emphasize is that this-the greatest ice-age of which we have evidence-was not due to the chilling of the atmosphere or of the sea but solely to the high latitudes into which Gondwanaland drifted. Long ago Tyndall pointed out that to describe a glacial age as an age of cold was an entire misconception; for, he said, if we calculated the energy necessary to evaporate the enormous masses of ice embodied in the ice-sheets from the sea we should describe a glacial age as a period of greater heat-not cold. What makes a glacial ice-sheet is the condition that in some part of the earth more snow should fall in winter than can be melted in the following summer. For this condition to be fulfilled not only must there be intense local winter cold but also an abundant supply of atmospheric moisture. These conditions can be well studied in Canada in which $I$ had the good fortune to live for twelve years. In Montreal the average winter snowfall was six feet on the level : drifts up to depths of fourteen feet were common. It was an ordinary experience to travel on ski or Indian snowshoes over the tops of buried fences. The ground under this snow-sheet was practically unfrozen. In 
contrast to Montreal, the snowfall at Winnipeg was less than a foot and the ground beneath was frozen to a great depth, and to this circumstance Winnipeg owed its magnificent wheat crops. As the spring began, the surface layer of the soil melted and the wheat grains pushed their radicles into this layer. As the sun grew stronger, the wheat roots grew longer and everywhere they encountered a reserve of water in the freshly melted ice of the soil.

How narrow was the margin which separated Eastern Canada from the inception of a new ice-age may be gathered by the following observations which were made by me. During the whole of one August the back gardens of many Montreal houses were encumbered by vast masses of unmelted snow. Now, the first snow of the winter is expected on November 1, and considerably before that period there are hard ground frosts at night. Even in September nights frosts occur, so that if in this particular autumn these frosts had been a little more continuous, a considerable portion of the August snow-drifts would have survived into the winter, and thus the formation of a new icesheet would have been begun.

Up to about 1880 the Pleistocene glacial age was the only one of which we had any geological evidence. When at last the conviction was forced on geologists that there had been a severe ice-age in Permo-Carboniferous times, the usual result followed : there was a wild scamper on the part of enthusiastic pioneers to find ice-ages in all periods of the world's history. Such ages were discovered in Cambrian, Ordovician, Silurian, Jurassic and Cretaceous times, and a fearful mess was made of glacial chronology. The pioneers always forgot that the ultimate cause of ice-ages was not the chilling of the atmosphere but greater evaporation from the sea. As the movement of an ice-sheet produces a mixture of thick clay with large stones, which easily becomes a conglomerate with lapse of time, it was easy to suggest a glacial origin for all the conglomerates which recur in the stratified series. If, however, glacial ages are due to the drift of land into high latitudes, then this drift must be somehow the result of the rotation of the earth and must follow an orderly course; we cannot at will 'ferry' lands over sea and back again in order to satisfy our theories.

There seems, however, to be a consensus of geological opinion that there was a Pre-Cambrian ice-age. The best evidence for this, in fact the only indubitable evidence, is found in Canada. In the Temiskaming region of Northern Ontario, where the Huronian strata have been exploited for the world-famous silver mines of Cobalt, a conglomerate with large boulders has been found. But these boulders, when extracted from the mother-rock, are found to have smooth surfaces marked by parallel striæ exactly like those found on boulders in the Pleistocene boulder clay or, for that matter, in the moraines of recent glaciers. Their glacial origin is, therefore, definitely proved. Other records of Huronian strata from other parts of Canada showing evidence of ice action are almost certainly fragments of the same deposit.

That there has been a northerly drift of secondary rocks since Permian times is shown by Old and New Red Sandstone beds of Europe and eastern Canada. The red colour of these sandstones is due to grains of laterite, but laterite is a degrada. tion product of granite and is only found in tropical regions. At the present day its formation is going on amongst the granite hills of Nigeria.

Whilst the Gondwana ice-age was raging in the south, contemporary beds in Spitsbergen show evidence of a warm tropical climate. There are beds of coal with fossil plants showing evidence of a rich tropical flora.

We have seen that drift into high latitudes affords a complete explanation of all glacial phenomena previous to the Pleistocene. When, however, we approach the consideration of the pleistocene glacial age we find that this explanation is no longer applicable. The Pleistocene glacial deposits are represented both in the northern and the southern hemispheres and were therefore contemporaneous all over the world. Further, in the Pleistocene glacial ages alone, do we find evidence of long-continued interruptions of glacial activity. During these interruptions stratified beds were laid down containing plants, bones and shells bearing testimony to a comparatively mild climate. There seem to have been at least four periods of intense cold separated by milder inter-glacial periods. The cold periods were named by Penck, the Gunz, the Mindel, the Reiss and the Würm. The most interesting thing about these periods is that the bones and tools of the oldest indubitably human race are found in the interglacial interval between the Würm and the Reiss periods.

Since the Pleistocene ice-period was world wide, its cause must be sought outside the south in the sun. If, as we have already stated, the primary cause of these periods is an increase in evaporation from the sea, there must have been increased radiation from the sun. Now some of the irregularly recurrent phenomena of the sun are sunspots. These are solar cyclones of enormous dimensions and are associated with intense radiation. They are connected with the well-known magnetic storms and with displays of aurora borealis. If, then, during a period extending over several million years there were frequently repeated 
increases in solar radiation, we should have increases in evaporation from the sea and consequent increases in precipitation in the colder regions of the earth. The interglacial periods would be associated with few sunspots and reduced evaporation and precipitation. During them the glaciers would gradually shrink, exposing great masses of boulder clay which would be washed away by the melting ice and deposited as thin bands of sand and clay elsewhere. Visitors to Switzerland who have noted the milk-white appearance of the Upper Rhone during the summer months will need no further reminder of the nature of the water issuing from the foot of a melting glacier.

Coleman, in his book ("Ice Ages"), mentions the continental drift theory but withholds his assent on the ground of the colossal forces necessarily assumed, which he holds to be incredible. But, as Sir Thomas Holland has pointed out, there is no possible escape from the conclusion that the tearing asunder of primitive continents and their drifting apart really did take place. Actually Greenland has been caught in the very act of drifting. A Danish observer, Oersted, has measured the change in longitude of a station in the extreme south of Greenland between the years 1922 and 1932. The amount determined was 600 feet, that is, 60 feet a year. If we calculate back 100,000 years, we find that Greenland must have then been lying close to Norway. Now from observations on the annual layers of silt deposited every summer by the streams fed by the melting ice, it has been ascertained that it is about 13,000 years since an ice-sheet covered the whole of Sweden. The great Würmian glaciation may have lasted 100,000 years to judge from the enormous extent of the boulder clay which it produced. On the west coast of Wales the clay and boulders carried by this icesheet which had crossed the Irish Sea were piled up to a depth of 200 feet. A period of 120,000 years would carry us back into the interglacial period between the Reiss and the Würm glaciations-the time indeed when Neanderthal man flourished.

When the exposed boulder clay became dried out it broke up into dust, and this under the name of 'loess' was blown about by the wind. In central China this loess is piled up to a depth of hundreds of feet. A similar degradation of soil into dust is taking place in North America.

We must conclude with a few words about the bearing of these climatic changes on evolution. What changes the Pre-Cambrian ice-epoch produced in life we do not know, but the researches of Prof. D. M. S. Watson and Dr. R. Broom on mammals prove that the growth of cold-blooded reptiles into warm-blooded mammals began directly after the Gondwana ice-age. During the Miocene epoch a continuous forest stretched across the Old World from the shores of France to the coast of China. Bones and skulls show that this forest was inhabited by the higher apes, the direct precursors of man; but in Pliocene times a northern drift of the old Africa and the Deccan of India began which, impinging on the tableland of central Asia, raised up the enormous barriers of the Himalayas and associated mountains and in Europe the Alpine chain.

Thus the ape population was cut into a northern and a southern group: the latter continued to find its living in the forest, where remnants of it persist as the chimpanzees, gorillas, orangs and gibbons of to-day. The northern group, however, had to face a more severe climate, the first beginning, in fact, of the Pleistocene ice-age. The forest gave way to steppe and the apes had to change their habits to hunting on the ground, and primitive hunting man was born.

Thus there would be much truth in the epigram : the Gondwana ice-age produced the warm-blooded mammals, the Pleistocene ice-age produced man.

\section{The Organization of Knowledge}

$\mathrm{T}$ HE unprecedented progress of science and its applications during the last hundred years has given rise to a flood of literature, the magnitude of which has dulled our senses into a sort of acquiescence. About two thousand new volumes on scientific subjects are issued annually by British publishers, while the number of scientific papers published in a year throughout the world has been estimated to amount to three quarters of a million. A century ago, a scientific worker was expected and able to digest for himself practically the whole of the original literature of his subject. To-day it is with difficulty that he can keep abreast of a particular part of it, even with the aid of a new type of abstracting and indexing literature, which has been evolved specially for this purpose. If he would seek to know what discoveries, which might be useful to him, have been recorded in other branches of his own and different sciences, he must depend entirely upon such services. 